\title{
Mempertahankan Eksistensi Tradisi Tungguk Tembakau melalui Media Sosial
}

\author{
Fanny Hendro ${ }^{1}$, Topan Setiawan ${ }^{2}$, Donna Setiawati ${ }^{3}$ \\ ${ }^{1,2}$ Program Studi Ilmu Komunikasi, Fakultas Ilmu Komunikasi, \\ ${ }^{3}$ Program Studi Teknik Informatika, Fakultas Ilmu Komputer, \\ Universitas Boyolali \\ Jl. Pandanaran Nomor 405, Boyolali, Jawa Tengah, 57314, Indonesia \\ E-mail: fanny.hap@gmail.com'; mastopan2020@gmail.com²; donna.setiawati@gmail.com* \\ *Corresponding author
}

\begin{abstract}
The Tungguk Tembakau Tradition in Senden Selo Village, Boyolali Regency only known among the local community because at that time it was not familiar with social media so that the outside community was not aware of this tradition. The purpose of this study is to analyze the role of digital communication in the existence of the Tungguk Tembakau Tradition, as a cultural heritage that needs to be preserved and to increase tourist visits in the area so that it will have an impact on increasing local income and the surrounding community. The research method used is qualitative research with a phenomenological approach. The data collection technique used interview techniques with the people of Senden Village as many as two people. The results of the research stated that the existence of the Tungguk Tembakau tradition is maintained and celebrated every year, this is because the role of digital communication used can inform the wider community about the existence of this local culture. The social media that are often used are Facebook, Youtube, and Instagram. The substance of this research contributes in the form of new policy recommendations to the Village Government of Senden regarding the application of the smart village concept to become a tourist village with programmed activities to improve community welfare.
\end{abstract} Keywords: Digital Communication; The existence of the Tungguk Tembakau Tradition; Phenomenology; Social media

\begin{abstract}
Abstrak
Tradisi Tungguk Tembakau di Desa Senden Selo Kabupaten Boyolali hanya dikenal dikalangan masyarakat setempat, karena saat itu belum mengenal media sosial, sehingga masyarakat luar tidak mengetahui adanya tradisi tersebut. Tujuan penelitian ini untuk menganalisis peran digital komunikasi dalam eksistensi Tradisi Tungguk Tembakau sebagai warisan budaya yang perlu dilestarikan dalam rangka meningkatkan kunjungan wisatawan di daerah tersebut, sehingga berdampak pada peningkatan pendapatan daerah dan masyarakat sekitarnya. Metode penelitian yang digunakan adalah penelitian kualitatif dengan pendekatan fenomenologi. Teknik pengumpulan data dengan teknik wawancara kepada dua orang warga Desa Senden. Hasil penelitian menunjukkan peran komunikasi digital yang digunakan mampu menginformasikan ke masyarakat luas atas keberadaan budaya lokal ini, sehingga eksistensi tradisi Tungguk Tembakau dapat terjaga dengan terlaksana setiap tahun. Media sosial yang sering dimanfaatkan adalah Facebook, Youtube, dan Instagram. Substansi penelitian ini memberikan kontribusi berupa rekomendasi kebijakan baru kepada Pemerintah Desa Senden terkait penerapan konsep smart village agar menjadi desa wisata dengan kegiatan yang terprogram untuk meningkatkan kesejahteraan masyarakat.
\end{abstract}

Kata kunci: Komunikasi Digital; Media Sosial; Eksistensi Tradisi Tungguk Tembakau; Fenomenologi

\section{Pendahuluan}

Desa Senden berada di Kecamatan Selo Kabupaten Boyolali, terletak di antara Gunung Merbabu, Gunung Merapi dan Gunung Lawu. Desa Senden dulunya merupakan daerah perkebunan. Pada masa kolonial Desa Senden menjadi sentra perkebunan teh dan kopi, namun setelah meninggalkan desa tersebut, Desa Senden berubah menjadi lahan pertanian holtikultura dan tembakau.

Masyarakat Desa Senden mempunyai tradisi setiap tahun yang bisa dinikmati oleh para wisatawan domestik maupun asing, yaitu Tradisi Tungguk Tembakau. Tradisi Tungguk Tembakau menjadi tradisi khas dan unik yang merupakan upacara ucapan rasa syukur penduduk setempat atas keberhasilan panen tembakau. Tradisi Tungguk Tembakau awalya dilakukan secara perorangan, namun beberapa tahun terakhir 
dilakukan secara bersama-sama sehingga dapat menarik wisatawan untuk hadir menyaksikan tradisi tersebut yang dikenal dengan Festival Tungguk Tembakau (Murdaningsih, 2018). Tradisi Tungguk Tembakau sebelum tahun 2016 dirayakan dengan sederhana dan hanya diketahui oleh masyarakat setempat. Masyarakat setempat membuat kenduri atau tumpeng sebagai wujud syukur atas hasil panennya. Pada saat itu pemerintah desa belum memanfaatkan media komunikasi digital untuk menyebarkan informasi terkait tradisi Tungguk Tembakau, sehingga tidak banyak orang yang mengetahui tentang tradisi tersebut.

Publikasi merupakan salah satu cara untuk mempromosikan atau mengenalkan potensi sumber daya alam dari suatu daerah. Pada zaman teknologi internet belum maju seperti saat ini, publikasi merupakan kegiatan yang membutuhkan biaya mahal. Publikasi yang dapat dilakukan pada saat itu hanya melalui media massa atau surat kabar dan televisi. Masyarakat Desa Senden ingin menginformasikan ke khalayak umum bahwa masyarakat setempat mempunyai sebuah tradisi budaya lokal yang khas dan unik yaitu tradisi Tungguk Tembakau yang masih dipertahankan eksistensinya, walaupun saat ini banyak tantangan dengan masuknya budaya barat pada era globalisasi. Upaya untuk mengenalkan dan mempromosikan tradisi tersebut sebagai potensi kekayaan budaya yang dimiliki masyarakat Desa Senden terkendala oleh mahalnya biaya publikasi saat itu, sehingga tradisi ini belum banyak diketahui oleh masyarakat luar.

Eksistensi tradisi ini perlu dijaga karena sebagai warisan budaya yang perlu dilestarikan. Pelestarian budaya ini juga untuk menunjukkan eksistensi tradisi Tungguk Tembakau agar tidak punah, oleh karena itu perlunya memanfaatkan kecanggihan teknologi. Kemajuan teknologi informasi terutama adanya internet membuat siapapun dapat melakukan publikasi atau promosi lebih mudah, cepat dan murah, apalagi saat ini didukung adanya media sosial.
Permasalahan yang dialami oleh masyarakat Desa Senden terkait eksistensi tradisi Tungguk Tembakau juga dialami oleh Komunitas Tanah Aksara yang berada di Bandung. Keduanya samasama berupaya ingin menunjukkan eksistensi dari budaya yang dimilikinya. Berdasarkan hasil penelitian yang telah dilakukan menyatakan komunitas tersebut memanfaatkan teknologi media sosial untuk menunjukkan eksistensinya ditengah masyarakat luas. Berdasarkan wawancara dengan pendiri komunitas tersebut, pada awal pendirian komunitas ini merasa kurang percaya diri dan merasa pesimis jika nantinya ide tersebut tidak direspon masyarakat, selanjutnya pendiri memutuskan membuat account media sosial sebagai wadah menuangkan ide serta agar dapat berekspresi secara bebas mengungkapkan mengenai eksistensi budaya komunitas tanah aksara. Penggunaan media komunikasi seperti Facebook, Fan Page, Twitter, dan Instagram. Penggunaan media sosial tersebut bertujuan untuk memberikan motivasi dan mengajak masyarakat dalam rangka menyebarluaskan produk karya cipta masyarakat setempat sehingga diharapkan dengan adanya komunitas tersebut akan dapat membuka lapangan pekerjaan baru, serta diharapkan dengan pemanfaatan media ini dapat untuk menjaga pelestarian budaya lokal tersebut (Sjafirah \& Prasanti, 2016).

Tradisi dapat diumpamakan sebagai kumpulan dari beberapa benda yang diberi makna khusus yang berasal dari masa lalu seperti material dan gagasan. Tradisi yang sudah bertahan lama dapat hilang jika ada penolakan maupun dengan sengaja dilupakan. Kebudayaan yang ada di tengah masyarakat yang sudah menjadi kebiasaan yang dilakukan secara berulang kali dan turun temurun juga dapat dikatakan sebagai sebuah tradisi (Sztompka, 2007).

Tradisi Tungguk Tembakau Desa Senden merupakan wujud rasa syukur atas melimpahnya hasil panen tembakau. Ritual diawali dengan acara kirab gunungan tembakau, gunungan hasil bumi, dan beberapa kesenian tradisional 
ikut mengiringi kirab tersebut. Prosesi ritual kirab di mulai dari Balai Desa Senden hingga makam petilasan Gunungsari yang berada di puncak bukit kaki Gunung Merbabu, dengan berjalan menanjak kurang lebih 2 kilometer. Warga mengenakan pakaian adat dalam ritual tersebut. Warga masyarakat Desa Senden mengikuti ritual dengan suka cita dan meriah serta ritual ini dilaksanakan secara serentak oleh sebelas dukuh di Desa Senden. (Widodo, 2019).

Eksistensi dapat diartikan sebagai suatu keberadaan budaya yang dilakukan terus menerus dan turun temurun secara defacto. Keberadaan dalam arti yang lain adalah adanya pengaruh atas ada atau tidak adanya keberadaan orang lain. Eksistensi dapat dijelaskan sebagai upaya respon dari orang disekitar lingkungan dimana kita berada sehingga hal ini membuktikan bahwa keberadaan kita diakui. Masalah keperluan akan nilai eksistensi ini sangat penting, karena ini merupakan pembuktian akan hasil kerja atau performa di dalam suatu lingkungan (Diansyah, 2011).

Perkembangan teknologisaatinimemberikan pengaruh positif terhadap mudahnya proses komunikasi dalam penyampaian informasi kepada masyarakat. Hal ini dikarenakan sudah tersedianya berbagai macam media yang dapat digunakan untuk menyampaikan informasi, sehingga tidak hanya mengunakan petugas informasi, melainkan saat ini penggunaan media dalam proses komunikasi dapat lebih dioptimalkan (Sjafirah \& Prasanti, 2016).

Daya tarik budaya lokal dapat memiliki nilai tambah dalam aspek ekonomi maupun investasi. Hal tersebut dapat dilakukan dengan upaya pelestarian dan pengembangan nilai-nilai budaya lokal. Pemanfaatan media sebagai media promosi budayalokalkeduniaberdampakbagipeningkatan nilai budaya lokal tersebut (Wardhanie, 2017). Penelitian yang dilakukan oleh Wardanie sejalan dengan penelitian ini yang dilakukan pada tradisi Tungguk Tembakau Desa Senden, yang mempunyai persamaan sebagai budaya lokal yang khas dan unik yang memiliki nilai tambah dengan memanfaatkan perkembangan teknologi media komunikasi dan informasi.

Eksistensi tradisi Tungguk Tembakau perlu dipertahankan, hal tersebut sejalan dengan penelitian yang dilakukan oleh Natalia (2013) pada masyarakat Desa Sumberejo yang berada di Kecamatan Ngablak Kabupaten Magelang. Desa tersebut memiliki sebuah tradisi Saparan atau Merti Desa yang mempunyai maksud agar hidup mendapatkan kesejahteraan dan dijauhkan dari marabahaya dan malapetaka. Seperti halnya dengan tradisi Tungguk Tembakau mempunyai maksud mengucapkan rasa syukur atas hasil panen yang melimpah. Pada perayaan Tradisi Saparan, pemilik rumah biasanya mengundang sanak keluarga, kerabat dan kawan-kawan untuk datang berkunjung kerumahnya pada hari pelaksanaan Saparan. Begitupun dengan perayaan Tungguk Tembakau, masyarakat membuat kenduri yang akan dimakan bersamasama dengan sanak keluarga. Penelitian terkait tradisi Saparan tersebut bertujuan untuk mengetahui pelaksanaan serta alasan yang mempengaruhi mengapa tradisi Saparan tersebut tetap dipertahankan oleh masyarakat Desa Sumberejo. Penelitian tersebut menggunakan metode kualitatif dan masyarakat desa Sumberejo sebagai subjek penelitian. Berdasarkan hasil penelitiannya terdapat tiga klasifikasi perayaan yang berlangsung secara berurutan pada pelaksanaan tradisi Sarapan yaitu perayaan komunal, perayaan individu dan perayaan yang bersifat hiburan. Ketiga perayaan tersebut mempunyai tujuan yang berbeda. Perayaan komunal dilakukan secara bersama di rumah Kepala Dusun untuk memanjatkan doa bersama agar mendapatkan kemakmuran dan keselamatan desa serta berdoa untuk memperkuat solidaritas diantara warga. Perayaan individu dilaksanakan di rumah masing-masing warga dengan tujuan untuk mempererat tali kekerabatan antarkeluarga. Perayaan hiburan bertujuan untuk meramaikan suasana Saparan. Saat ini pelaksanaan Saparan 
telah mengalami pergeseran. Masyarakat tidak lagi memperhatikan aspek komunal yaitu acara doa bersama, namun penduduk setempat mengambil inti secara praktis dari tradisi Saparan, yaitu slametan bersama, mengundang semua orang seperti kawan, kenalan serta kerabat sanak saudara untuk datang dan makan bersama serta bersilaturahmi ke rumah. Tradisi saling mengundang inilah yang merupakan ciri khas dalam Saparan. Dalam kehidupan sosial masyarakat desa Sumberejo menyakini bahwa tradisi Saparan tersebut masih dirasakan sangat fungsional. Beberapa fungsi yang dimiliki dari tradisi tersebut antara lain fungsi pembawa kemakmuran, fungsi menjaga ikatan kekerabatan, fungsi menjaga ikatan solidaritas dan kerukunan warga, fungsi hiburan, dan fungsi menjaga warisan budaya. Berdasarkan fungsi-fungsi tersebut maka masyarakat Desa Sumberejo masih mempertahankan tradisi Saparan (Natalia, 2013).

Mempertahankan budaya lokal Indonesia di era globalisasi perlu memanfaatkan peran media digital (Wardhanie, 2017). Globalisasi ditunjukkan dengan adanya kemajuan dibidang teknologi informasi dan komunikasi. Masyarakat dipaksa untuk menuju modernitas dan harus berupaya tetap eksis di muka bumi ini, karena hal tersebut merupakan bagian dari konsekuensi adanya kemajuan teknologi. Globalisasi selain memberikan dampak positif juga dapat menimbulkan dampak negatif. Dampak negatif yang terjadi, salah satunya adalah banyaknya unsur budaya asing yang masuk ke wilayah Indonesia. Budaya asing dapat masuk dengan mudah ke tengah masyarakat karena kurangnya pengawasan dan tidak adanya perangkatperangkat yang mampu menampung budaya asing tersebut agar tidak langsung diterima oleh masyarakat. Hal ini dikhawatirkan jika masyarakat langsung menyerap budaya asing tersebut tanpa memperdulikan identitas nasional. Oleh karena itu, untuk mengatasi kekhawatiran tersebut maka perlu-menentukan strategi agar budaya lokal tetap dapat bertahan.
Strategi yang dapat dipilih dan dilakukan adalah menjadikan beberapa media sebagai alat untuk menyebarkan atau mempromosikan kebudayaan Indonesia. Kemajuan teknologi saat ini dengan memanfaatkan jaringan internet dapat digunakan untuk meningkatkan peran kebudayaan lokal yang lebih dikenal secara internasional. Beberapa media yang dapat digunakan seperti blog atau social media.

Penelitian yang dilakukan oleh Sjafirah \& Prasanti (2016) menyatakan tentang budaya lokal yang ada di Bandung yaitu Komunitas Tanah Aksara yang tetap eksis saat ini dengan memanfaatkan media komunikasi. Komunitas tersebut menyakini bahwa dengan memanfaatkan kemajuan teknologi informasi dan komunikasi dapat sebagai media untuk mempertahankan kelestarian budaya serta meningkatkan nilai-nilai budaya lokal.

Perkembangan media komunikasi dan informasi dapat berperan menjadikan sebuah kebudayaan lokal yang unik dan khas menjadi sebuah produk yang mempunyai nilai tinggi. Perlu upaya agar budaya lokal dapat dikenal ke seluruh dunia dengan menjadikan media bertaraf nasional maupun internasional sebagai alat memasarkan budaya tersebut. Jika hal tersebut dapat dilakukan, maka dapat menaikkan daya tarik budaya lokal dan dapat mempengaruhi daya tarik dibidang ekonomi yaitu terkait investasi.

Dampak dari adanya kemajuan teknologi saat ini membuat perubahan pada bidang teknologi, telekomunikasi, transportasi dan bidang pariwisata. Permasalahan lunturnya warisan budaya dapat muncul pada kondisi seperti ini. Globalisasi tidak perlu ditolak, karena dapat menjadi penghambat kemajuan teknologi dan ilmu pengetahuan. Tindakan yang perlu dilakukan adalah menentukan strategi yang dapat meningkatkan daya tahan budaya lokal dalam menghadapi globalisasi tersebut.

Ermawan (2017) menyatakan bahwa upayaupaya pelestarian budaya tradisi di era globalisasi saat ini ditemukan faktor-faktor penghambat 
yaitu faktor eksternal dan faktor internal. Faktor eksternal seperti kurangnya sosialisasi dari pihak yang bertanggungjawab dalam menangani masalah tersebut maupun peran media sebagai sarana public relations yang menjembatani informasi informasi kepada masyarakat. Peran masyarakat juga penting untuk mengajarkan kepada generasi muda untuk ikut melestarikan budaya yang dimiliki. Faktor internal seperti rendahnya sikap nasionalisme individu untuk mencintai budaya asli Indonesia. Hal ini dipengaruhi oleh faktor pola hidup individualisme yang menyebabkan minimnya kesadaran untuk memiliki sesuatu secara Bersama-sama.

Faktor pendorong masyarakat dalam melestarikan Tradisi Kirab Suran menurut (Puspasari, 2020) adalah adanya faktor internal dan faktor eksternal. Faktor internal antara lain yang berasal dari dalam diri setiap individu. Individu memiliki hati Nurani dan dorongan kesadaran untuk melestarikan kebudayaan yang dianggap berpengaruh pada keselamatan diri, adanya rasa toleransi dalam diri untuk menghargai warisan nenek moyang dan timbulnya rasa takut karena kebudayaan tersebut memiliki makna yang berdampak pada keselamatan diri. Sedangkan faktor pendorong dari eksternal antara lain adanya koordinasi yang baik antara golongan tua dan muda, tempat dimana seluruh golongan masyarakat berkumpul, melestarikan kebudayaan dari warisan nenek moyang, dan mengenalkan tradisi kebudayaan kepada pemuda dan anak-anak.

Dalam rangka melindungi budaya lokal Indonesia ditengah situasi masuknya arus globalisasi yang pesat, maka strategi yang dapat digunakan dengan memanfaatkan akses kemajuan teknologi informasi dan komunikasi sebagai pelestari dan pengembang nilai-nilai budaya lokal. Budaya lokal yang khas dapat menjadi suatu produk yang memiliki nilai tambah tinggi apabila disesuaikan dengan perkembangan media komunikasi dan informasi. (Wardhanie, 2017). Pengalaman hidup yang dialami oleh warga setempat perlu diketahui dalam upaya melestarikan budaya tersebut, maka perlunya pendekatan fenomenologi untuk mengetahui makna dan pengalaman yang dialami oleh penduduk setempat. Hal tersebut merupakan urgensi penelitian ini selain bertujuan untuk menganalisis peran digital komunikasi dalam eksistensi Tradisi Tungguk Tembakau sebagai warisan budaya yang perlu dilestarikan dalam rangka meningkatkan kunjungan wisatawan sehingga berdampak pada peningkatan pendapatan daerah dari masyarakat sekitarnya.

\section{Metode Penelitian}

Lokasi penelitian di Desa Senden Kecamatan Selo Kabupaten Boyolali. Objek penelitian adalah masyarakat Desa Senden karena sebagai pelaku kegiatan tradisi Tungguk Tembakau. Berdasarkan tujuan penelitian maka jenis penelitian yang digunakan adalah penelitian kualitatif dengan pendekatan fenomenologi. Penelitian fenomenologi melihat yang dialami oleh manusia dari sudut pandang orang yang mengalaminya secara langsung.

Pengumpulan data primer-penelitian ini dengan melakukan wawancara mendalam menggunakan pertanyaan-pertanyaan terbuka yang diajukan kepada informan. Informan terdiri dari Kepala Desa sekaligus sebagai sesepuh atau orang yang dituakan, Carik sekaligus sebagai panitia dan karangtaruna. Data sekunder didapat dari buku kepustakaan, televisi, koran, majalah dan internet.

Adapun tahapan-tahapan pengumpulan data sebagai berikut: 1). Proses memasuki lokasi, merupakan langkah awal seperti mencari informan. 2). Saat berada di lokasi, menemui informan yang telah ditentukan sebelumnya sebagai sumber data selanjutnya dilakukan wawancara. 3). Berupaya mengumpulkan data, dengan cara wawancara dengan narasumber, hal ini dilakukan untuk mengetahui kejadian, pandangan, kegiatan, pendapat dan perasaan dalam merayakan tradisi Tungguk Tembakau. 
Wawancara dilakukan secara informal atau santai, interaktif atau percakapan dua arah, dan melalui pertanyaan yang sudah disiapkan sebelumnya dan jawaban terbuka. Peneliti juga melakukan observasi atau pengamatan agar mendapatkan data yang valid dari informasi atau keterangan yang diperoleh di setiap lokasi. Observasi dengan melakukan pengamatan atas objek yang diteliti yaitu pada saat perayaan tradisi Tungguk Tembakau berlangsung. Selain itu,juga dilakukan pengumpulan data dengan mendokumentasikan data yang diperoleh dilapangan.

Hasil catatan dilapangan berisi deskripsi rinci dan akurat mengenai kondisi lapangan. Hal ini diperlukanuntukmelengkapidatadanmendukung landasan-landasan teori serta mempertajam analisis terhadap tradisi Tungguk Tembakau.

Data atau informasi yang diperoleh dari hasil wawancara dikumpulkan dan selanjutnya diolah untuk proses analisa data. Proses analisa data yang digunakan adalah deskriptif kualitatif yang merupakan proses penyederhanaan data kedalam bentuk yang mudah untuk dibaca dan diinterpretasikan (Besra, 2012)

Tahapan dalam proses analisis data meliputi reduksi, penyajian data dan penarikan kesimpulan data. Tahap reduksi data adalah mengumpulkan catatan-catatan tertulis hasil dari wawancara kepada informan yang selanjutkan data atau informasi tersebut dipilih dan dikelompokkan sesuai dengan kebutuhan penelitian terkait tradisi Tungguk Tembakau. Peneliti melakukan pengelompokkan data berdasarkan pertanyaan penelitian yang sudah disiapkan sebelumnya yang telah mendapatkan jawaban atau klarifikasi dari infroman yang meliputi faktor eksternal, faktor internal dan peran media digital pada Tradisi Tungguk Tembakau. Data atau informasi yang tidak dibutuhkan atau tidak diperlukan dalam penelitian ini dibuang. Tahap berikutnya adalah penyajian data, yaitu hasil wawancara dirangkai atau disusun secara sistematis agar mudah dipahami. Pada tahap ini, pertanyaan dan jawaban informan disusun dan dibuat narasi sesuai permasalahan penelitian. Tahapan berikutnya adalah melakukan penarikan kesimpulan dan verifikasi yaitu narasi yang telah dibuat dan disusun pada tahap sebelumnya perlu dilakukan aktifitas pengulangan atau di cek kembali untuk memastikan bahwa informasi tersebut benar-benar digunakan dalam penelitian ini. Tahap ini perlu dilakukan untuk menghindari perbedaan persepsi atau kesalahan interprestasi dari hasil wawancara dengan informan yang dapat mengaburkan makna persoalan penelitian. Proses validasi data-dilakukan untuk membuktikan apakah hasil yang diamati oleh peneliti telah sesuai dengan kenyataan dilapangan. Validasi pada penelitian ini menggunakan proses triangulasi sumber data, yaitu membandingkan data hasil pengamatan dilapangan pada saat perayaan tradisi tersebut berlangsung dengan hasil wawancara dengan informan (Lexy J. Moleong, 2019).

\section{Hasil Penelitian dan Pembahasan}

Penjelasan hasil penelitian ini didasarkan pada diagram fishbone pada Gambar 1. Sebuah tradisi dapat pudar atau tidak eksis lagi karena dipengaruhi oleh faktor eksternal dan faktor internal.

\section{Faktor Eksternal}

Faktor Eksternal yang dibutuhkan agar dapat mempertahankan eksistensi tradisi Tungguk Tembakau adalah adanya peran pemerintah dan peran pihak ketiga (stakeholder). Berikut pernyataan dari kepala desa terkait hal tersebut:

"Festival Tungguk Tembakau pertama kali diadakan pada tahun 2016. Tradisi ini sebelumnya sudah ada tapi sebatas kenduri biasa. Festival ini sudah masuk ke dalam program kerja desa dan sudah masuk daftar kegiatan Kabupaten Boyolali. Pemerintah Daerah Kabupaten Boyolali membantu kegiatan festival ini dengan memberikan bantuan berupa dana. Bantuan yang diterima oleh Desa Senden untuk operasional kegiatan festival pada Tahun 2019 sebesar 200 Juta. Perayaan festival ini juga setiap tahunnya dihadiri oleh Gubernur Jawa Tengah yaitu Bapak Ganjar Pranowo. Pada Tahun 2020 
Pemerintah Daerah juga memberikan bantuan dana namun karena kondisi pandemi Covid 19 maka festival ditiadakan untuk sementara. Tetapi sebagai gantinya diadakan acara peringatan tradisi tersebut secara sederhana pada hari Rabu Kliwon tanggal 12 Agustus 2020 dengan mengumpulkan pengurus RT dan RW serta tokoh lingkungan setempat. Pelaksanaan kenduri dilaksanakan di makam Gunung Sari pada malam hari. Kegiatan ini mendapatkan bantuan dari desa setempat berupa dana desa" (Wawancara dengan Kepala Desa, 2 September 2020)

\section{Dukungan pihak luar lainnya berasal dari kampus Universitas Indonesia (UI)} khususnya dari Program Studi Sastra Jawa. Penyelenggaran festival biasanya membentuk kepanitian yang terdiri dari panitia khusus desa dan panitia dari kampus UI. Anggota panitia yang terlibat ditunjuk oleh desa. Selain kerjasama dengan pihak kampus, kegiatan festival ini juga didukung oleh Perusahaan Djarum dan Gudang Garam dalam bentuk dana.

Faktor eksternal dapat mempengaruhi sebuah tradisi budaya yang sudah dilakukan secara turun temurun tetap eksis atau dapat juga tradisi tersebut pudar atau punah. Pengaruh budaya luar yang dibawa oleh penduduk pendatang atau penduduk baru yang masuk ke suatu daerah dapat mengikis budaya lokal yang ada didaerah tersebut. (Febriana \& Jonyanis, 2017). Hasil penelitian terdahulu yang dilakukan di desa Kotobaru terkait tradisi turun mandi bayi, yang berangsur berkurang karena masyarakat lokal sudah berinteraksi dengan masyarakat luar yang memiliki pemikiran yang lebih logis tentang kepercayaan tradisi tersebut. Faktor eksternal lainnya adalah munculnya kesenian baru yang menggeser budaya lokal yang ada. Perubahan nilai budaya disebabkan masyarakat saat ini telah sadar bahwa sebuah tradisi yang dilaksanakan hanya membuang-buang uang, sehingga tradisi tersebut dibuat lebih praktis untuk mempermudah dan mempersingkat waktu. Perubahan sosial masyarakat juga merupakan faktor eksternal yang berdampak pada bergesernya sebuah tradisi. Hal tersebut dikarenakan adanya perkembangan teknologi informasi dan komunikasi yang canggih yang dapat mengakibatkan ketegangan sosial berupa kecemburuan sosial antar individu (Setyaningsri, 2016).

Peran masyarakat Desa Senden terutama perangkat desanya telah ikut berperan mengajarkan kepada generasi mudanya dalam hal ini karang taruna untuk ikut serta dalam penyelenggaraan festival Tungguk Tembakau. Karang taruna walaupun dilibatkan pada kegiatan pendukung saja bukan inti namun hal ini dapat menambah rasa kecintaan generasi muda pada budaya yang dimilikinya. Kerjasama antara golongan tua dan muda terlihat pada saat kegiatan festival itu berlangsung. Golongan tua menjalankan perannya sebagai pelaku yang mengikuti ritual tersebut sedangkan golongan muda menjalankan perannya untuk menjaga situasi dan menjaga agar ritual ini berjalan lancar dengan menyiapkan sarana dan prasarana yang dibutuhkan.

Penelitian lain yang mendukung penelitian ini yaitu penelitian terkait tradisi Sambatan yang ada di masyarakat dusun Gamplong IV Sleman telah bergeser atau pudar karena dipengaruhi oleh faktor eksternal dan faktor internal. Berdasarkan hasil penelitian yang dilakukan menyatakan faktor internal yang menyebabkan pudarnya Tradisi Sambatan adalah melemahnya rasa gotong royong, masyarakat sudah kurang peduli dan tidak peka lagi terhadap kegiatan sambatan atau gotong royong ini. Hal tersebut karena banyak masyarakat yang bekerja di luar rumah untuk mencukupi kebutuhan hidupnya bahkan ada yang bekerja sampai malam atau lembur, sehingga tidak mempunyai waktu lagi untuk ikut berpartisipasi dalam kegiatan kemasyarakatan yang ada di dusun tersebut. Selain itu, faktor individual yang tinggi, tidak mau tahu kondisi lingkungan sekitarnya dan kesadaran masyarakat sudah berkurang atas keberadaan Tradisi Sambatan. Sedangkan faktor eksternal adalah gaya hidup masyarakat yang 
sudah berubah. Peralatan pertukangan dan pertanian yang akan digunakan sudah modern dan praktis sehingga tidak perlu banyak orang untuk membantu. Sistem Sambatan sudah bergeser atau pudar karena tidak lagi didasarkan sukarela tetapi karena sistem bayaran. (Arianto, 2019)

Hasil penelitian ini berbeda dari peneliti terdahulu di atas berbeda dengan pengaruh luar yang diberikan oleh pihak luar pada tradisi Tungguk Tembakau. Masuknya pihak ketiga yaitu Universitas Indonesia dan perusahaan rokok justru memberikan bantuan berupa pemikiran dan dana agar tradisi Tungguk Tembakau tetap eksis. Masyarakat Desa Senden sadar bahwa dengan adanya bantuan pihak ketiga membuat desa Senden dan tradisi Tungguk Tembakau menjadi lebih dikenal masyakat luas. Hal ini terbukti pada saat perayaan festival tersebut banyak pengunjung dari daerah lain yang datang untuk menyaksikan. Tamu undangan yang hadir dari Pemerintah Kabupaten Boyolali dan dari Pemerintah Jawa Tengah. Panitia telah menyiapkan prosesi perayaan tradisi tersebut tidak hanya berisi kesenian lokal, namun festival tersebut juga dimeriahkan dengan mendatangkan artis dan band musik dari ibukota. Kedatangan artis dan band musik tersebut menambah kemeriahan dan antusias warga yang datang mengikuti festival Tradisi Tungguk Tembakau. Kemunculan band modern ditengah perayaan festival ini hanya sebagai hiburan semata. Kesenian lokal seperti tari-tarian khas Desa Senden tetap menjadi unsur utama dari perayaan tersebut.

\section{Faktor Internal}

Tradisi Tungguk Tembakau dapat eksis sampai saat ini tentunya dikarenakan adanya faktor internal yang mendukung hal tersebut. Faktor internal seperti kemauan masyarakat untuk ikut menjaga tradisi sangat diperlukan. Faktor internal dapat berdampak pada eksistensi sebuah tradisi atau bahkan berdampak pada pergeseran atau perubahan sebuah tradisi.
Tradisi sebuah budaya mengalami perubahan karena adanya dorongan dari diri masyarakat setempat. Faktor pendidikan dan pola pikir yang telah maju serta adanya penduduk yang heterogen merupakan faktor internal yang dapat menyebabkan bergesernya nilai budaya atau berubahnya tradisi budaya setempat (Febriana \& Jonyanis, 2017). Pernyataan sebelumnya bahwa pola pikir masyarakat merupakan salah satu faktor internal yang dapat mempengaruhi perubahan sebuah tradisi didukung hasil penelitian yang dilakukan oleh (Praditaningtyas, 2015). Selain itu faktor internal yang mempengaruhi perubahan tradisi adalah munculnya kreatifitas baru seperti contohnya tradisi pertunjukkan seni sandur oleh senimannya tetap dipertahankan namun diubah menjadi kesenian hiburan yang dapat ditukarkan dengan uang. Sifat personal tentang bagaimana memandang sebuah tradisi itu berbeda satu dengan yang lainnya dan adanya perkembangan pengetahuan dan teknologi menyebabkan penemuan pemikiran baru berupa unsur kebudayaan baru dapat mempengaruhi perubahan sebuah tradisi. Selain itu faktor kondisi keuangan juga mempengaruhi dalam menentukan sebuah ritual (Setyaningsri, 2016).

Berdasarkan hasil wawancara dengan Kepala Desa membuktikan bahwa masyarakat mempunyai kemauan untuk menjaga tradisi ini adalah masyarakat ikut memeriahkan acara festival dengan berpartisipasi mengikuti kegiatan kesenian dan kemasyarakatan yang diselenggarakan oleh panitia. Kegiatan kesenian di antaranya adalah lomba tari-tarian dan karawitan. Kegiatan kemasyarakatan adalah jalan sehat keliling kebun. Selain itu pada tahun 2016 pernah diadakan pertunjukkan wayang dengan dalangnya $\mathrm{Ki}$ Anom Suroto dan mendatangkan band besar dari Jakarta.

Masyarakat Desa Senden baik golongan tua atau golongan muda sadar bahwa tradisi Tungguk Tembakau ini memiliki makna yang diyakini berdampak bagi kehidupan masyarakat setempat. Masyarakat mempunyai 
rasa takut jika tradisi ini tidak dijalankan. Hal ini karena masyarakat menyakini bahwa hasil panen tembakau yang selalu melimpah berkat doa dan rasa syukur yang dipanjatkan pada setiap ritual ditahun-tahun sebelumnya. Panen tembakau melimpah dan harga jual yang tinggi memengaruhi kesejahteraan masyarakat setempat. Masyarakat dapat membeli kebutuhan hidup dan membiayai keperluan yang lain seperti biaya sekolah anak, biaya menikah, biaya membeli ternak serta kebutuhan yang lain.

Masyarakat Desa Senden masih memiliki rasa gotong royong bukan seperti masyarakat kota yang memiliki rasa individual. Hal inilah yang mempengaruhi masyarakat setempat masih memiliki rasa mencintai budaya asli Indonesia khususnya budaya lokal, sehingga Tradisi Tungguk Tembakau sampai saat ini tetap terjaga berkat masyarakat setempat dan tokoh-tokoh masyarakatnya. Hal tersebut disampaikan oleh Kepala Desa Senden.

Tahapan ritual tradisi Tungguk Tembakau adalah sebagai berikut: 1) membuat sesaji atau kenduri 2) mendatangi makam 3) panen tembakau 4) membawa arak-arakan hasil panen. Tahap pertama masyarakat membuat sesaji atau kenduri berupa tumpeng nasi beserta lauk pauknya dapat berukuran kecil maupun besar. Selain itu masyarakat juga membuat tumpeng yang berisi hasil bumi seperti sayuran. Pada saat kenduri, masyarakat membawa beberapa tumpeng tersebut seperti Tumpeng besar (tumpeng desa), tumpeng tembakau, dan tumpeng sayuran. Pada tahap pertama ini, sesaji tersebut dibawa ke makam sebagai sarana persembahan untuk leluhur dan berdoa memohon ijin. Ritual yang dilakukan sebelum kegiatan festival dimulai adalah mendatangi (sowan adalah bahasa Jawa) ke makam Gunung Sari untuk meminta ijin. Makam tersebut memiliki penjaga atau juru kunci yaitu Bapak Harjo Warsidi dan yang dimakamkan adalah Syeh Kerto Muhammad. Berdasarkan informasi dari Kepala Desa adanya hubungan makam tersebut dengan tradisi tungguk tembakau, maksudnya adalah sebelum masyarakat melakukan ritual diharuskan terlebih dahulu mendatangi makam tersebut untuk meminta ijin. Panen tembakau yang dilakukan oleh masyarakat Desa Senden disebut tungguk. Tungguk ke ladang tembakau dengan membawa sesaji, sebagai tempat rasa bersyukur kepada Allah karena diberi hasil panen yang baik dan melimpah. Selanjutnya tumpeng-tumpeng tersebut dibawa secara arak-arakan dari balai desa sampai ke makam Gunung Sari. Prosesinya adalah tumpeng tersebut diserahkan oleh kepala desa kepada juru kunci, setelah itu diserahkan kembali kepada masyarakat. Prosesi selanjutnya adalah acara pemetikan tembakau, yang-biasanya dilakukan oleh Bapak Gubernur Jawa Tengah. Setelah acara dimakam selesai maka tumpeng-tumpeng tersebut dibawa pulang ke Dukuh Gunung Sari. Masyarakat dan wisatawan menunggu disepanjang jalan untuk dapat mengambil tumpengan secara berebutan (rayahan=jawa). Masyarakat yang mengikuti acara rayahan mempercayai bahwa mendapatkan keberkahan hidup jika dapat mengambil beberapa isi dari tumpeng. Dalam kegiatan rayahan ini biasanya panitia sudah mengatur agar tidak terjadi rebutan massal yang dapat mengakibatkan kecelakaan atau jatuh korban karena saling berdesakan antar masyarakat yang mengikuti ritual ini. Panitia mengambilkan isi dari tumpeng tersebut dan dibagikan kepada masyarakat yang tidak ikut berdesakan khususnya warga yang berusisa tua. Tradisi ini tidak hanya mengundang warga Desa Senden namun juga semua warga yang menanam tembakau diseluruh Kecamatan Selo. Desa lain yang berada dalam satu Kecamatan Selo diminta untuk ikut berpartisipasi dalam festival ini.

Festival budaya atau arak-arakan budaya berlangsung setelah perayaan Tungguk Tembakau selesai dilakukan. Desa Senden mempunyai beberapa kesenian tarian seperti Reog, Topeng Ireng, dan Butho Gedruk. Iring-iringan tarian tersebut dimulai dari balai desa sampai makam lalu berakhir dilapangan Desa Brajan. 
Tabel 1 Media yang digunakan untuk Promosi

\begin{tabular}{|c|c|c|}
\hline No & Media yang Digunakan & Alamat URL \\
\hline 1 & Facebook & $\begin{array}{l}\text { https://www.facebook.com/tungguktembakaufestival/?ti } \\
=\text { as }\end{array}$ \\
\hline 2 & Youtube & $\begin{array}{l}\text { https://www.youtube.com/channel/UCaoMIC8Hsg4ZzT } \\
\text { TRLJHms3w }\end{array}$ \\
\hline 3 & Instagram & $\begin{array}{l}\text { https://instagram.com/tungguktembakaufestival?igshid= } \\
\text { 1ro8xvtitlklq }\end{array}$ \\
\hline
\end{tabular}

Sumber: Hasil olahan peneliti (2020)

Bapak Carik menjelaskan bahwa dalam menjalankan tradisi ini tidak ada paksaan, artinya bahwa masyarakat setempat sudah menjalankan tradisi secara turun temurun dan diyakini oleh masyarakat lereng Gunung Merapi dan Gunung Merbabu adanya tradisi ini dapat membawa rejeki dan berkah khususnya untuk para petani tembakau. Hal ini sejalan dengan penelitian terdahulu yang dilakukan oleh Natalia (2013) mengenai tradisi Saparan di Desa Sumberejo Magelang, yang berfungsi sebagai pembawa kemakmuran, menjaga ikatan kekerabatan, menjaga ikatan solidaritas dan kerukunan warga, hiburan, dan menjaga warisan budaya.

Beberapa saran yang diberikan olek Bapak carik untuk masyarakat setempat agar tradisi ini tetap terjaga adalah a) ikut berpartisipasi apabila ada kegiatan dalam rangka pelestarian kebudayaan. b) generasi penerus perlu diajarkan mengenai kebudayaan ini agar kebudayaan itu tidak musnah dan tetap dapat bertahan c) budaya sendiri perlu dicintai tanpa harus merendahkan dan melecehkan budaya orang lain.

Peran serta generasi muda dibutuhkan untuk berperan aktif dalam upaya melestarikan dan menjaga nilai-nilai kearifan budaya lokal. Peran pemerintah daerah untuk mengambil kebijakan dalam bentuk himbauan agar sebuah tradisi dilaksanakan secara turun temurun dan memasukkannya sebagai materi muatan lokal pada kurikulum sekolah (Suparno, 2018).
Berdasarkan hasil penelitian terdahulu, faktor internal lain yang membawa pengaruh terhadap eksistensi budaya adalah faktor pendidikan dan pola pikir yang berbeda-beda. Nyatanya faktor tersebut tidak memberikan pengaruh kepada masyarakat Desa Senden. Masyarakat dengan tingkat pendidikan yang berbeda antara satu dengan yang lain tidak mempengaruhi masyarakat untuk mengubah atau mengabaikan tradisi Tungguk Tembakau. Seluruh lapisan asyarakat Desa Senden sadar akan pentingnya mempertahankan tradisi Tungguk Tembakau sebagai warisan nenek moyang yang perlu dilestarikan.

Padahasil penelitian terdahulu, faktor kondisi keuangan dapat mempengaruhi pergeseran budaya, namun pada tradisi Tungguk Tembakau faktor keuangan warga tidak memberikan pengaruh terhadap pergeseran budaya, karena setiap rumah tetap membuat tumpeng atau kenduri sederhana sebagai ungkapan rasa syukur atas hasil panen yang diperoleh. Bagi warga setempat membuat tumpeng bukan paksaan namun sudah menjadi tradisi dan ritual ini dilakukan dengan rasa gembira dan bahagia. Masyarakat biasanya sudah mempersiapkan diri jauh sebelum ritual ini dilaksanakan dengan membeli kebutuhan untuk persiapan membuat tumpeng.

Tradisi Tungguk Tembakau tetap terjaga dan dilestarikan karena adanya peran pemerintah desa atas kepedulian kepala desa beserta jajarannya dan para sesepuh yang berkomitmen tetap terus melestarikan tradisi Tungguk Tembakau dengan membuat perayaan setiap tahunnya. 


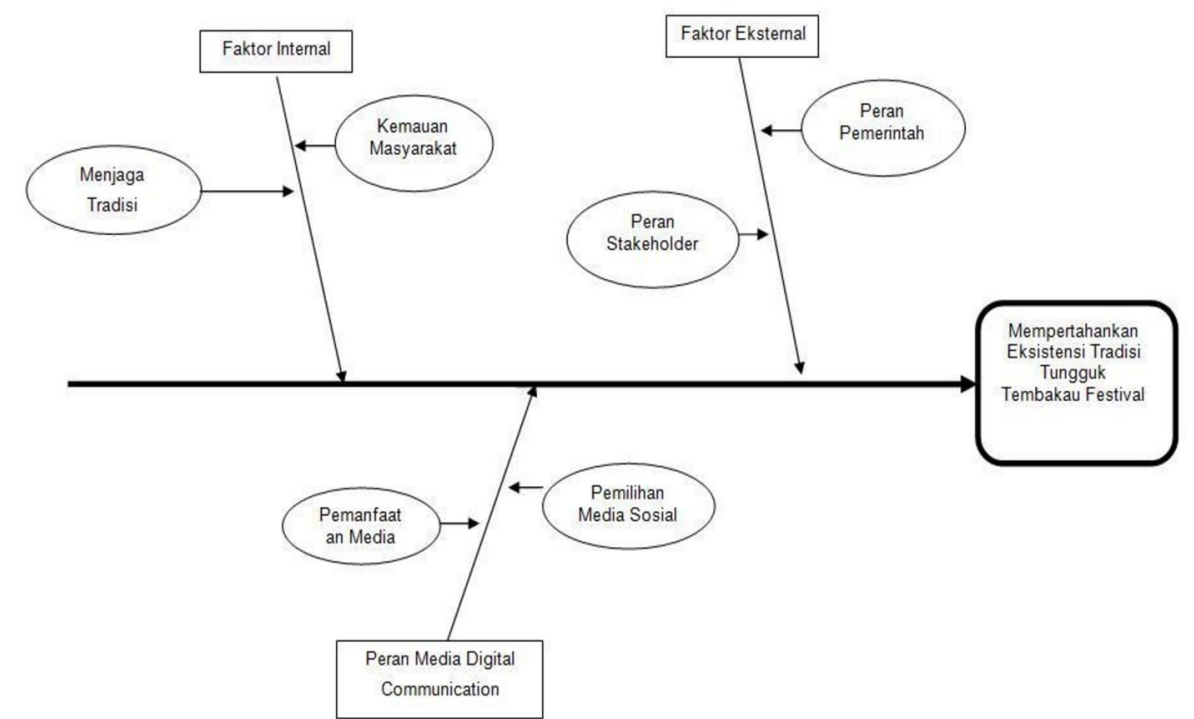

Gambar 1 Diagram Fisbone Identifikasi dalam Mempertahankan Eksistensi Budaya

Sumber: Arianto (2019)

\section{Peran Media Sosial}

Peran media sosial untuk meyebarkan informasi dalam upaya menjaga tradisi Tungguk Tembakau kepada masyarakat luas sangat dibutuhkan. Media sosial mempunyai peranan sebagai agen yang dapat membantu membentuk budaya masyarakat (Muhammad Khairul Nizam Jensani et al., 2019). Saat ini penggunaan media sosial menjadi sarana baru untuk beradu eksistensi antar individu didunia maya dengan menyebarluaskan foto atau gambar hasil selfie (Raditya, 2016). Pemilihan media salah satunya media massa dapat berperan sebagai sarana yang dapat dimanfaatkan untuk membantu masyarakat dalam menghadapi arus globalisasi, hal tersebut karena media massa dapat mempengaruhi pemikiran dan tingkah laku masyarakat dalam menghadapi budaya luar yang masuk (Surahman, 2016). Perlu diwaspadai bahwa globalisasi mempunyai pengaruh negatif bagi kebudayaan bangsa Indonesia (Surahman, 2013).

Berdasarkan informasi dari Carik Desa Senden yaitu Bapak Agus Haryanto yang sekaligus sebagai panitia acara festival Tungguk Tembakau Tahun 2019 menyatakan adanya anggaran khusus yang disiapkan untuk pembiayaan media promosi festival tersebut. Dana yang disiapkan sebesar 25 Juta, untuk mempersiapkan festival ini memerlukan waktu sekitar tiga bulan. Kepanitiaan dibentuk setiap menjelang diselenggrakannya kegiatan festival. Dalam kepanitian tersebut juga melibatkan karangtaruna. Hal itu diperlukan karena saat festival berlangsung banyak undangan yang hadir Keterlibatan karang taruna biasanya untuk parkiran, urusan panggung dan kesenian. Selain itu muda mudi karangtaruna dilibatkan dalam kegiatan festival dengan tujuan agar ikut menjaga tradisi tersebut.

Dalam menentukan media yang akan digunakan ada tim khusus yang menangani hal tersebut. Salah satu tugas panitia adalah pemilihan media yang digunakan untuk mempromosikan festival tersebut. Setiap tahun ketika festival diselenggarakan, wartawan dari beberapa media dan juga mahasiswa Universitas Indonesia memberikan bantuan dalam mempromosikan festival tersebut. Mahasiswa tersebut yang membantu promosi melalui media sosial. Beberapa media sosial yang digunakan terlihat pada Tabel 1 . 
Dukungan lainnya berasal dari Dinas Kominfo Kabupaten Boyolali, yaitu dengan membuat dokumentasi kegiatan sekaligus memyebarkan informasi kepada masyarakat luas.

Bapak Carik menjelaskan bahwa adanya mediasosialsangatmembantuuntukmengenalkan kepada masyarakat Indonesia tentang tradisi adat kebudayaan Tungguk Tembakau yang harus dilestarikan dan dikembangkan. Hal ini menandakan bahwa pemanfaatan media sosial dapat menjadi sarana untuk menunjukkan eksistensi tradisi Tungguk Tembakau.

Hal tersebut sejalan dengan penelitian yang dilakukan Wardhani (2017) bahwa dengan memanfaatkan akses kemajuan teknologi informasi dan komunikasi dapat sebagai pelestari dan pengembang nilai-nilai budaya lokal. Tradisi Tungguk Tembakau yang merupakan budaya lokal bisa dipasarkan keseluruh dunia sehingga daya tariknya dapat menarik investor. Selain menggunakan media sosial, media lain yang digunakan adalah memasang MMT (Metro media Tecnologies) atau biasa disebut spanduk atau banner. Setiap padukuhan yang ada di Desa Senden dipasangi MMT. Selain itu MMT dipasang di sepanjang jalan dari desa hingga Kota Boyolali.

Berdasarkan hasil penelitian yang telah dibahas, penggunaan media komunikasi digital dianggap efektif sebagai wadah yang menunjukkan eksistensi tradisi Tungguk Tembakau. Masyarakat luas dapat melihat dan menikmati keindahan tradisi ini melalui berbagai media sosial yang dimiliki. Hal ini karena perayaan tradisi Tungguk Tembakau baik secara visual berupa foto maupun video dapat dilihat di media sosial seperti Facebook maupun Instagram.

Penelitian terdahulu yang dilakukan oleh (Fajrin, 2015) tidak sejalan dengan penelitian ini. Pada penelitian Fajrin penggunaan gadget atau smartpone pada siswa SDNU 1 Gresik tidak ada hubungannya terhadap eksistensi permainan tradisional. Siswa memiliki gadget untuk bermain game sendiri. Permainan tradisional yang dulunya dimainkan secara
Bersama-sama, namun saat ini tidak dimainkan lagi. Memiliki gadget hanya untuk merasa dirinya gaul dan tidak ketinggalan jaman.

Hasil penelitian ini sejalan atau mendukung penelitian yang pernah dilakukan oleh Sjafirah \& Prasanti (2016). Penelitian tersebut menyatakan bahwa penggunaan media komunikasi dalam eksistensi budaya lokal bagi Komunitas Tanah Aksara di Bandung bisa digunakan sebagai media untuk mengajak masyarakat agar tetap melestarikan budaya lokal tersebut. Begitu pula dengan masyarakat Desa Senden tetap melestarikan tradisi Tungguk Tembakau dengan memanfaatkan teknologi komunikasi digital. Budaya lokal akan memiliki nilai tambah maka harus mampu mengikuti perkembangan teknologi. Masyarakat yang hidup di era ini, dapat memanfaatkan alat komunikasi yang canggih untuk mendapatkan informasi lebih cepat. Masyarakat dapat mencari berbagai informasi terkait tradisi Tungguk Tembakau seperti sejarah tradisi, kapan dilaksanakan festival, lokasi festival, dan informasi terkait transportasi untuk menuju desa tersebut.

Pemilihan media dan pesan berkaitan dengan penentuan target yang menjadi sasaran wisatawan perlu dilakukan dengan cermat. Pembagian target sasaran wisatawan lokal maupun wisatawan mancanegara dapat memengaruhi pemilihan media yang digunakan. Seperti halnya Kota Semarang telah mengembangkan Program Semarang Smart City, yang memanfaatkan peran teknologi yang dapat mengakses informasi salah satunya aspek pariwisata yang disebut Tourism 4.0 (Mardhiyani, 2020)

Terkait tradisi Tungguk Tembakau, pemerintah desa Senden telah menggunakan dan memilih media yang digunakan untuk promosi yaitu facebook, youtube dan instagram. Pemerintah desa telah menunjuk pejabat atau beberapa panitia untuk mengurus dan mendokumentasikan segala urusan yang berkaitan dengan perayaan tradisi Tungguk Tembakau. Dokumen yang disimpan adalah foto- 
foto perayaan yang disimpan dalam bentuk buku dan tersimpan pada dokumentasi dunia maya seperti di facebook, youtube dan instagram. Dokumentasi dibuat dengan tujuan agar ritual atau tradisi kebudayaan ini tidak hilang begitu saja. Diharapkan generasi muda dapat melihat kembali perayaan-perayaan tersebut melalui media sosial yang telah disebarkan. Kemajuan teknologi seperti adanya internet dapat sebagai media promosi yang efektif. Generasi muda khususnya karang taruna Desa Senden dapat menyebarkan budaya lokal seperti Tungguk Tembakau melalui media sosial yang dimiliki sehingga budaya ini akan semakin dikenal luas. Dampak lain dari promosi ini adalah banyaknya kunjungan wisatawan lokal maupun internasional yang tertarik datang ke Desa Senden selain untuk menyaksikan langsung festival Tungguk Tembakau maupun datang untuk sekedar menikmati keindahan alamnya.

Pemerintah desa dapat mencontoh program Kota Semarang dengan memiliki Program Smart Village. Program yang dibuat dapat berisi informasi pariwisata di Kecamatan Selo yang didalamnya salah satu destinasi wisatanya adalah perayaan Tradisi Tungguk Tembakau Konsep smart village atau desa cerdas adalah desa tersebut secara inovatif menggunakan teknologi informasi untuk mencapai peningkatan kualitas hidup (Herdiana, 2019). Terdapat tiga elemen penting dalam proses pengembangan smart village yang saling mempengaruhi yaitu smart government, smart community dan smart environment. Keterlibatan pemerintah desa, masyarakat setempat dan lingkungan pedesaan merupakan elemen yang saling bekerjasama untuk mencapai tujuan bersama yaitu terbentuknya Smart Village (Herdiana, 2019).

Pengembangan konsep smart village atau desa cerdas dapat diterapkan di Desa Senden, hal ini karena desa tersebut memiliki sebuah tradisi budaya yaitu Tungguk Tembakau yang dapat digunakan sebagai pemberdayaan masyarakat dan juga sekaligus dapat untuk meningkatkan kesejahteraan masyarakat setempat. Festival Tungguk Tembakau yang diadakan pada tahun 2019 terbukti dapat menarik banyak wisatawan lokal maupun mancanegara yang datang menyaksikan festival tersebut. Penerapan konsep tersebut dapat berhasil jika ada pendekatan bottom-up yaitu pendekatan yang dimulai dari masyarakat atas prakarsa dan keinginan masyarakat sendiri dengan melakukan identifikasi yang valid terhadap berbagai permasalahan yang ada di masyarakat Senden seperti nilai karakter budaya maupun norma-norma yang berlaku di desa tersebut. Proses pengembangan dapat melalui penguatan, kesadaran dan partisipasi terhadap elemen Smart Village. Saat ini pemerintah desa telah berbenah diri dengan memperbaiki berbagai sarana dan prasarana untuk menunjang sebagai desa wisata yang nyaman untuk dikunjungi.

\section{Simpulan}

Berdasarkan hasil penelitian dapat disimpulkan bahwa tradisi Festival Tungguk Tembakau hingga saat ini masih terjaga dan tetap dilestarikan. Masyarakat setempat menjaga tradisi ini dengan tetap membuat kenduri sebagai ungkapanrasabersyukuratashasilpanentembakau yang baik. Festival perayaan diselenggarakan setiap tahun dengan partisipasi masyarakat setempat dan didukung oleh pemerintah daerah serta pihak kampus. Festival Tungguk Tembakau dikenal masyarakat luas karena adanya peran media sosial yang digunakan. Hal tersebut didukung oleh teknologi internet yang dapat digunakan untuk mengakses media sosial seperti facebook, instragram, youtube dan lainnya.

Implikasi penelitian ini membuat Desa Senden dikenal luas oleh masyarakat. Wisatawan yang datang tidak hanya untuk menyaksikan festival tradisi Tungguk Tembakau namun juga dapat melihat keindahan Desa Senden yang berada di lereng Gunung Merapi dan Merbabu. Hal tersebut dapat meningkatkan kunjungan wisatawan di Desa Senden. Hasil 
penelitian diharapkan dapat digunakan sebagai rekomendasi kebijakan bagi pemerintah daerah maupun pemerintah desa agar tradisi Tungguk Tembakau menjadi salah satu destinasi wisata di Kabupaten Boyolali yang terprogram melalui smart village. Dalam rangka meramaikan potensi desa Senden, pemerintah desa dapat membuat berbagai kegiatan yang terprogram seperti menyiapkan wisata kuliner (promosi produk UKM) yang dimiliki oleh masyarakat setempat, membuat destinasi bertahap seperti mengenalkan objek wisata yang lain yang ada disekitar desa Senden dan terjadwal agar kedepannya dapat memberikan pemasukan untuk kas desa serta menggarap fasilitas umum agar wisatawan yang datang lebih merasa nyaman. Selain itu agar eksistensi tradisi tetap terjaga dibutuhkan sumber daya manusia yang berkompeten dibidang teknologi informasi sehingga data dan informasi terkait budaya lokal selalu terdokumentasikan dengan baik.

\section{Ucapan Terima Kasih}

Penelitian ini dapat terlaksana atas bantuan beberapa pihak, untuk itu ucapkan terima kasih diberikan kepada Ristekdikti yang telah memberikan hibah penelitian, Kepala Desa Senden beserta perangkatnya sebagai narasumber serta Mahasiswa yang telah membantu mengumpulkan data (Feri Setiawan dan Yulia Mayasari).

\section{Daftar Pustaka}

Arianto, W. (2019). Faktor-Faktor Penyebab Pudarnya Tradisi Sambatan Dalam Masyarakat Dusun Gamplong IV, Sumberahayu, Moyudan, Sleman [Universitas Negeri Yogyakarta]. https://eprints.uny.ac.id/28517/ Besra, E. (2012). Potensi Wisata Kuliner Dalam Mendukung Pariwisata Di Kota Padang. Jurnal Riset Akuntansi Dan Bisnis, 12(1), 74-101.

Diansyah, A. (2011). Eksistensi Damang Sebagai Hakim Perdamaian Adat Pada Masyarakat Suku Dayak di Palangkaraya. Universitas Udayana.
Ermawan, D. (2017). Pengaruh Globalisasi terhadap Eksistensi Kebudayaan di Indonesia. Jurnal Kajian LEMHANNAS RI. Fajrin, O. R. (2015). Hubungan Tingkat Penggunaan Mobile Gadget Dan Eksistensi Permainan Tradisional Pada Anak Sekolah Dasar. Jurnal Idea Societa. Febriana, R., \& Jonyanis. (2017). Perubahan Sosial pada Tradisi Turun Mandi Bayi di Desa Kotobaru Kecamatan Singingi Hilir Kabupaten Kuantan Singingi. Jurnal Online Mahasiswa Fakultas Ilmu Sosial Dan Ilmu Politik Universitas Riau. Herdiana, D. (2019). Pengembangan Konsep Smart Village Bagi Desa-Desa di Indonesia (Developing the Smart Village Concept for Indonesian Villages). JURNAL IPTEKKOM : Jurnal Ilmu Pengetahuan \& Teknologi Informasi, 21(1), 1. https://doi. org/10.33164/iptekkom.21.1.2019.1-16 Lexy J. Moleong, D. M. A. (2019). Metodologi

Penelitian Kualitatif (Edisi Revisi). PT. Remaja Rosda Karya. https://doi. org/10.1016/j.carbpol.2013.02.055 Mardhiyani, N. L. (2020). Tourism 4.0: Strategi komunikasi pemasaran pariwisata kota semarang. Jurnal Kajian Media, 4(1). https://doi.org/10.25139/jkm.v4i1.2384 Muhammad Khairul Nizam Jensani, Eswaran, K., \& Noor, S. S. M. (2019). Media Sosial dan Pembentukan Budaya Menurut Islam. Prosing Seminar Sains Teknologi Dan Manusia 2019 (SSTM'19). Murdaningsih. (2018, August 7). Mengenal Potensi Desa Senden di Boyolali. Republika. https://www.republika.co.id/berita/ nasional/umum/18/08/07/pd342w368mengenal-potensi-desa-senden-di-boyolali Natalia, A. (2013). Eksistensi Tradisi Saparan Pada Masyarakat Desa Sumberejo Kecamatan Ngablak, Kabupaten Magelang. Universitas Negeri Semarang. 
Praditaningtyas, I. (2015). Pertunjukan Seni Sandur (Studi Tentang Perubahan Tradisi Pertunjukan Seni Sandur Sebagai Bagian Dari Ritual Setelah Panen Di Kabupaten Tuban). Jurnal Mahasiswa Sosiologi, 1(1), 58. http://jmsos.studentjournal. ub.ac.id/index.php/jmsos/article/view/58

Puspasari, R. L. P. L. (2020). Partisipasi Masyarakat Pada Pelestarian Upacara Tradisi Kirab Suran Di Dusun Kembangarum Donokerto Kecamatan Turi Kabupaten Sleman Kota Yogyakarta. Jurnal Pendidikan Sosiologi, 1-17. Raditya, M. H. (2016). Selfi e dan Media Sosial pada Seni sebagai Wujud Eksistensi. Jurnal Ilmu Sosial Dan Ilmu Politik, 18(1), 26. https://doi.org/10.22146/jsp.13096 Setyaningsri, M. (2016). Perubahan Tradisi RuwatanAnak Tunggal Di Desa Kedungharjo Kecamatan Bangilan Kabupaten Tuban Tahun 2000-2015. Avatara, 5(1), 1350-1362. Sjafirah, N. A., \& Prasanti, D. (2016). Penggunaan Media Komunikasi dalam Eksistensi Budaya Lokal bagi Komunitas Tanah Aksara; Studi Deskriptif Kualitatif tentang Penggunaan Media Komunikasi dalam Eksistensi Budaya Lokal bagi Komunitas Tanah Aksara di Bandung. Jurnal Ilmu Politik Dan Komunikasi, VI(2), 39-50.
Suparno, G. A. dkk. (2018). Mempertahankan Eksistensi Budaya Lokal Nusantara Ditengah Arus Globalisasi Melalui Pelestarian Tradisi Gawai Dayak Sintang. Jurnal Pendidikan Dan Kewarganegaraan, 3(1), 43-56. http://jurnal.stkippersada.ac.id/jurnal/ index.php/PEKAN/article/view/144/140 Surahman, S. (2013). Dampak Globalisasi Media Terhadap Seni dan Budaya Indonesia. Jurnal Komunikasi, 2(1), 29-38. https://e-jurnal.lppmunsera.org/ index.php/LONTAR/article/view/334/378

Surahman, S. (2016). Determinisme Teknologi Komunikasi dan Globalisasi Media Terhadap Seni Budaya Indonesia. REKAM: Jurnal Fotografi, Televisi, Dan Animasi, 12(1), 31. https://doi.org/10.24821/rekam.v12i1.1385

Sztompka, P. (2007). Sosiologi perubahan sosial. In Revista Iberoamericana de Ciencias (Issue 2007, p. 206). Wardhanie, A. P. (2017). Peranan Media Digital dalam Mempertahankan Budaya Lokal Indonesia di Era Globalisasi. Prosiding Strengthening Local Communities Facing The Global Era, 1, 348-354. http://jurnal.unmuhjember. ac.id/index.php/pslcf/article/view/915 Widodo, T. (2019). Makna Simbol Tradisi Tungguk Tembakau Desa. Senden Kecamatan. Selo Kabupaten. Boyolali. In IAIN Surakarta (Vol. 23, Issue 3). 